\title{
Managerial Stress Management As An Asset In People Management Being A Marketing Strategy Element
}

Article history

Received: 28 April 2013

Sent for revision: 28 June 2013

Received in revised form: 02 July2013

Accepted: 04 July 2013

Available online: 11 July 2013

\begin{abstract}
Any service organization operating under turbulent market conditions must have a successful marketing strategy. A successful marketing strategy implies proper management of all elements within a marketing mix: service package, price, distribution channels, promotion, service process, service ambience and people. People, i.e. primarily the employed within an organization are one of the elements that must be appropriately considered when drawing up and implementing a marketing strategy. Proper personnel management must nowadays include good management of managerial stress. Adequate managerial stress management is preconditioned by successful identification of sources of managerial stress. The aim of this paper is to present the importance of proper and timely identification of sources of managerial stress. The paper demonstrates the carried out scientific research based on a method that is universal for all types of organizations, regardless of their type and activity, in order to precisely identify the sources of managerial stress and define its proper management, as an asset in people management, which is an element of marketing strategy. The research was conducted using a survey, sampling 100 employees in 13 organizations throughout Serbia. Survey results indicated that the most important sources of managerial stress are: participation in decision-making, selection process, earnings, and time and deadlines pressure. Therefore, recommendations are provided for directing identified sources of managerial stress towards successful management of people as an element of marketing strategy.
\end{abstract}

\footnotetext{
${ }^{1}$ Educons University, Faculty of Business Economics, Novi Sad - Sremska Kamenica, profradnovic@gmail.com

${ }^{2}$ Raiffeisen bank, Novi Sad, vladanastanojev@yahoo.com
} 
Radnović B. et al.: Managerial Stress Management As An Asset In People...

Key words: marketing strategy, people, employees, managerial stress, sources of managerial stress, proper management

\section{Upravljanje menadžerskim stresom u funkciji upravljanja ljudima kao element marketing strategije}

Apstrakt: Svaka uslužna organizacija koja posluje u turbulentnim tržišnim okolnostima mora imati uspešnu marketing strategiju. Uspešna marketing strategija podrazumeva pravilno upravljanje svim elementima marketing miksa: uslužnim paketom, cenom, kanalima distribucije, promocijom, procesom usluživanja, uslužnim ambijentom i ljudima. Ljudi, odnosno u prvom redu zaposleni unutar organizacije su jedan od elemenata kojem se mora posvetiti adekvatna pažnja prilikom koncipiranja i realizacije marketing strategije. Danas, adekvatno upravljanje zaposlenima mora da podrazumeva $i$ kvalitetno upravljanje menadžerskim stresom. Preduslov kvalitetnog upravljanja menadžerskim stresom je uspešno identifikovanje izvora menadžerskog stresa. Cilj ovog rada je da pokaže značaj pravilnog $i$ blagovremenog identifikovanja izvora menadžerskog stresa. $U$ radu je predstavljeno sprovedeno naučno istraživanje zasnovano na metodu koji je univerzalan za sve vrste organizacija, bez obzira na njihov tip i delatnost, kako bi se pravilno identifikovali izvori menadžerskog stresa $i$ definisalo adekvatno upravljanje istim, u funkciji upravljanja ljudima kao elementom marketing strategije. Istraživanje je vršeno putem ankete, na uzorku od 100 zaposlenih, u okviru 13 organizacija na teritoriji Srbije. Rezultati ankete su pokazali da su najznačajniji izvori menadžerskog stresa: participacija $u$ donošenju odluka, proces selekcije, zarada i pritisak vremena i rokova. Stoga date su preporuke za usmeravanje identifikovanih izvora menadžerskog stresa u pravcu uspešnog upravljanja ljudima, kao elementom marketing strategije.

Ključne reči: marketing strategija, ljudi, zaposleni, menadžerski stres, izvori menadžerskog stresa, pravilno upravljanje

\section{Introduction}

Successful marketing strategies of service organizations are based on adequate management of marketing mix elements: service package, price, distribution channels, promotion, service process, service ambience and people (Radnović, 2013).

Thus, one of the elements of marketing strategy of any service organization is people, i.e. primarily the employed within a service organization. To this end, 
great attention must be obviously paid to them, in all phases of management, i.e. both during selection, and development and motivation.

The theory holds that all elements of marketing strategy are equally important for successful implementation of marketing strategy (Kotler, 2007). However, people or employees are an element of marketing strategy which largely influences on both the implementation of other marketing strategy elements and successful implementation of overall marketing strategy and achievement of positive business results (Radnović, 2013). The impact of people on creating marketing mix and service layout is therefore immense (Ilic \& Radnović, 2010). On the other hand, people management proves to be not an easy task, especially today when employees in any organization are exposed to a turbulent business environment.

Working in a changeable business environment, employees are faced with a number of external and internal factors, which exert a direct or indirect impact on their behaviour and business results (lkač, 2005).

Any organization striving for a successful marketing strategy must analyze macro-environmental and micro-environmental factors that affect the organization or their employees, thereby shaping the manner of people management as an element of marketing strategy.

The most important external factors (Andrejević \& Radnović, 2010), which among other things, influence managerial stress are: market, demographic conditions, technology, economics, culture, politics, legislation and similar elements that act on a universal basis.

Internal factors (Andrejević \& Radnović, 2011), or often mentioned as organizational ones, which affect managerial stress are: organizational structure, organizational culture, participation in decision-making, etc.

Management of people, or employees, is therefore a complex multidisciplinary process. It implies appropriate management of human resources (Pržulj, 2011), and, within the same, a proper selection, motivation, communication, adequate system of reward/punishment, etc, as well as adaptation to changes (Vujić, 2009), in accordance with the requirements of internal and external environment. Marketing managers are the main creators of marketing management strategies, thus being obliged and responsible for proper management of human resources. Inadequate people management as an element of marketing strategy is actually caused by: poor recruitment, role ambiguity and conflict of interest, poor evaluation and rewarding system, lack of teamwork, insufficient power, etc. (Veljković, 2009). However, poor people management as an element of marketing strategy is essentially founded on mismanagement of existent managerial stress and failure to maintain it within optimal limits (Andrejević \& Radnović, 2011), where each employee can make its best efforts in performing work tasks. Potentially possible organizational 
Radnović B. et al.: Managerial Stress Management As An Asset In People...

sources of managerial stress can be: conflict of roles, unfamiliarity with responsibilities, lack of necessary information, inadequate organizational structure, inappropriate organizational culture, performance of uncreative (repetitive) tasks, time pressure, etc. (Mihailović, D. \& Borovnjak, V., 2008.).

Proper management of managerial stress as an asset to people management being an element of marketing strategy must primarily emphasize the research and identification of potential sources of managerial stress, which was the aim of the conducted research presented in this paper.

The importance of this scientific research is based on the fact that proper people management as an element of marketing strategy is significantly dependant on timely detection of managerial stress, in order to optimally manage and channel the stress within productive framework.

The scientific research was aimed to providing a universal framework of scientific research for identification of potential sources of managerial stress, and thus enabling management of people, and therefore marketing strategy, to achieve positive results. The scientific contribution of this research lies in the effort to answer the open existing question of proper and timely identification, as well as optimal management of managerial stress in people management as an element of marketing strategy. To this end, potentially possible universal and scientific-research model was presented, that could be applied as such or in partially modified form to identify the source of managerial stress regardless of the type, activity, scope and purpose of the organization's operations.

\section{Methodology of Research}

A universal model was designed for the purpose of scientific research, i.e. scientific-research questionnaire, which should serve all organizations in identifying some potential organizational sources of managerial stress. The analysis of research results will enable introduction of recommendation set for optimal management, with the aim of better people management as an element of marketing strategy.

Scientific-research questionnaire contains 11 questions, i.e. 3 general and 8 subject-related questions.

General questions relate to gender (male, female), age (18 - 30, $31-40,41$ $-50,51-60$, over 60 ) and level of education (primary education, secondary education, college degree, university degree, master degree, PhD degree).

Subject-related part of the questionnaire was created based on the research issues regarding potential organizational sources of managerial stress 
Radnović B. et al.: Managerial Stress Management As An Asset In People...

observed in the context of people management as an element of marketing strategy.

Subject-related part of the questionnaire contained 8 questions and related to subjects' attitudes towards the following potential sources of managerial stress within the organization:

- organizational structure,

- corporate culture,

- participation in decision-making,

- responsibility,

- creative, exciting and challenging job,

- selection process,

- earnings,

- time and deadlines pressure.

The possible answers to each subject-related question were as follows:

- never,

- sometimes,

- often,

- always.

The research was conducted on the field, covering randomly selected sample of 100 subjects in 13 different organizations operating in the Republic of Serbia, from $1^{\text {st }}$ March 2013 to $31^{\text {st }}$ March 2013.

Table 1 - Organizations covered by the conducted research

\begin{tabular}{|c|c|}
\hline & NAME OF ORGANIZATION \\
\hline 1 & Petroleum Industry of Serbia Novi Sad \\
\hline 2 & Public Enterprise for City Construction and Development Novi Sad \\
\hline 3 & Carlsberg Serbia \\
\hline 4 & Societe Generale Bank \\
\hline 5 & Uniqa Insurance \\
\hline 6 & Elektorvojvodina \\
\hline 7 & Novi Sad Fair \\
\hline 8 & Delhaize Serbia \\
\hline 9 & DDOR Novi Sad \\
\hline 10 & National Bank of Serbia \\
\hline 11 & JKP Čistoća Novi Sad \\
\hline 12 & JKP Put Novi Sad \\
\hline 13 & Nectar Bačka Palanka \\
\hline
\end{tabular}


Radnović B. et al.: Managerial Stress Management As An Asset In People...

Participants in the research were the employees in the organizations listed in the above table.

After research was conducted, all data were processed in tabular and graphical manner. Basic mathematical and statistical methods were used, as well as analysis and synthesis. The analysis of each potential source of managerial stress provided specific conclusions. Finally, having identified the sources of managerial stress, certain recommendations were introduced for proper management of managerial stress as an asset in management of people as an element of marketing strategy.

Distribution of subjects by gender, age and level of education was as follows:

Table 2 - Gender distribution of subjects

\begin{tabular}{|l|c|}
\hline \multicolumn{2}{|c|}{ GENDER DISTRIBUTION OF SUBJECTS } \\
\hline MALES & 58 \\
\hline FEMALES & 42 \\
\hline TOTAL & 100 \\
\hline
\end{tabular}

The sample of 100 subjects comprised 58 males and 42 females.

Table 3- Age distribution of subjects

\begin{tabular}{|l|c|}
\hline \multicolumn{2}{|c|}{ AGE DISTRIBUTION OF SUBJECTS } \\
\hline $18-30$ years & 13 \\
\hline $31-40$ years & 41 \\
\hline $41-50$ years & 24 \\
\hline $51-60$ years & 19 \\
\hline over 60 years & 3 \\
\hline TOTAL & 100 \\
\hline
\end{tabular}

The sample of 100 subjects consisted of 13 subjects aged 18 to 30,41 subjects aged 31 to 40,24 subjects aged 41 to 50,19 subjects aged 51 to 60 , and 3 subjects aged over 60 .

The sample of 100 subjects comprised 1 subject with primary education, 45 subjects with secondary education, 19 subjects holding college degree, 32 subjects with university degree, 2 subjects with master degree, and 1 subject with PhD degree. 
Radnović B. et al.: Managerial Stress Management As An Asset In People...

Table 4 - Level of education of subjects

\begin{tabular}{|l|c|}
\hline \multicolumn{2}{|c|}{ LEVEL OF EDUCATION OF SUBJECTS } \\
\hline PRIMARY EDUCATION & 1 \\
\hline SECONDARY EDUCATION & 45 \\
\hline COLLEGE DEGREE & 19 \\
\hline UNIVERSITY DEGREE & 32 \\
\hline MASTER DEGREE & 2 \\
\hline PhD DEGREE & 1 \\
\hline TOTAL & 100 \\
\hline
\end{tabular}

\section{Results and Discussions}

Obtained answers to subject-related questions were processed and presented in the following manner:

QUESTION NO. 1 - Can you successfully perform your job in the existing organizational structure?

Table 5 - Organizational structure

\begin{tabular}{|c|c|}
\hline ANSWERS & NUMBER \\
\hline NEVER & 10 \\
\hline SOMETIMES & 19 \\
\hline OFTEN & 47 \\
\hline ALWAYS & 24 \\
\hline$\Sigma$ & 100 \\
\hline
\end{tabular}

To the first subject-related question, about existing organizational structure and successful performance of work, 71 subjects answered that they can always or often successfully perform their job in the existing organizational structure. It can be concluded that the existing organizational structure does not pose an obstacle for a subject to successfully perform the job, and therefore a source of managerial stress was not identified in the context of people management as an element of marketing strategy.

Further analysis indicates men have lower identification of the organizational structure as a source of managerial stress. With this regard, successful work performance in the existing organizational structure is higher in men than in women, regardless of their age, level of education and the organization where they work. 
Radnović B. et al.: Managerial Stress Management As An Asset In People...

QUESTION NO. 2 - Can you sufficiently well perform your assignments in the existing corporate culture?

Table 6 - Corporate culture

\begin{tabular}{|c|c|}
\hline ANSWERS & NUMBER \\
\hline NEVER & 1 \\
\hline SOMETIMES & 16 \\
\hline OFTEN & 57 \\
\hline ALWAYS & 26 \\
\hline$\Sigma$ & 100 \\
\hline
\end{tabular}

To the second subject-related question, about existing corporate culture and good execution of job, 83 subjects responded that they can always or often well perform their job in the existing corporate culture. It can be concluded that the existing corporate culture does not pose an obstacle for subjects to good performance of their job. Therefore, corporate culture was not identified as a source of managerial stress in the context of people management as an element of marketing strategy.

Further analysis indicates that successful performance of job based on the corporate culture criteria is higher in men and in women younger than 40, holding college or university degree. With this regard, it is noted that these groups present lower identification of corporate culture as a source of managerial stress. In addition, it was noticed that men show lower identification of corporate culture as a source of managerial stress. Consequently, the conclusion can be drawn that men have higher successful performance of job in the existing corporate culture than women, regardless of age, level of education, and the organization where they work. A significant variation in identification of source of managerial stress other than corporate culture is observed in older men with secondary education.

QUESTION NO. 3 - Do you sufficiently participate in the decision-making, given your position in the organization?

Table 7 - Participation in decision-making

\begin{tabular}{|c|c|}
\hline ANSWERS & NUMBER \\
\hline NEVER & 15 \\
\hline SOMETIMES & 42 \\
\hline OFTEN & 32 \\
\hline ALWAYS & 11 \\
\hline$\Sigma$ & 100 \\
\hline
\end{tabular}


To the third subject-related question, referring to establishing adequate participation in decision-making, given the position in the organization, 43 subjects responded that they always or often get a sufficient participation. It leads to the conclusion that subjects' participation in decision-making with regard to their position in the organization is considered as a source of managerial stress in the context of people management as an element of marketing strategy.

Further analysis finds that majority of men and women under age of 40 with obtained secondary education, believes they do not sufficiently participate in the decision-making, and thus identifies it as a source of managerial stress. In addition, it is observed that men show lower identification of participation in the decision-making as a source of managerial stress, compared to women. Hence conclusion is drawn that men participate more in the decision-making, regardless of their age, level of education, and the organization where they work.

QUESTION NO. 4 - Do you know exactly what you are responsible for?

Table 8 - Responsibility at work

\begin{tabular}{|c|c|}
\hline ANSWERS & NUMBER \\
\hline NEVER & 1 \\
\hline SOMETIMES & 8 \\
\hline OFTEN & 25 \\
\hline ALWAYS & 66 \\
\hline$\Sigma$ & 100 \\
\hline
\end{tabular}

When asked the fourth subject-related question on how familiar they are with their responsibilities at work, even 91 subjects responded they always or often precisely know what they are responsible for. It can be concluded that subjects' familiarity with responsibilities does not pose an obstacle to good performance of their job. Therefore, familiarity with responsibilities at work was not identified as a source of managerial stress in the context of people management as an element of marketing strategy.

Further analysis indicates that familiarity with responsibilities at work is lower only in women with secondary education, regardless of their age, and the organization where they are employed.

QUESTION NO. 5 - Do you find your job creative, exciting and challenging? 
Radnović B. et al.: Managerial Stress Management As An Asset In People...

Table 9 - Creative, exciting and challenging job

\begin{tabular}{|c|c|}
\hline ANSWERS & NUMBER \\
\hline NEVER & 13 \\
\hline SOMETIMES & 23 \\
\hline OFTEN & 46 \\
\hline ALWAYS & 18 \\
\hline$\Sigma$ & 100 \\
\hline
\end{tabular}

To the posed fifth subject-related question, on how much their job is creative, exciting and challenging, 64 subjects responded they always or often have a creative, exciting and challenging job. It can be concluded that whether a job is creative, exciting and challenging is not an obstacle for subjects to well perform their job. Therefore, creative, exciting and challenging job was not identified as a source of managerial stress in the context of people management as an element of marketing strategy.

Further analysis finds that the vast majority of subjects to 40 years of age, with obtained secondary education, regardless of gender, believe to have a creative, exciting and challenging job, thus do not identify it as a source of managerial stress. Having reviewed the entire sample of selected subjects, conclusion can be made that job is more creative, exciting and challenging in men than in women, and accordingly men have lower identification of creative, exciting and challenging job as a source of managerial stress.

QUESTION NO 6. - Is the selection process in your organization adequate and proper?

Table 10 - Selection process - adequacy and properness

\begin{tabular}{|c|c|}
\hline ANSWERS & NUMBER \\
\hline NEVER & 26 \\
\hline SOMETIMES & 38 \\
\hline OFTEN & 19 \\
\hline ALWAYS & 17 \\
\hline$\Sigma$ & 100 \\
\hline
\end{tabular}

Results of the sixth subject-related question on adequacy and properness showed that 36 subjects find the selection process in their organization to be always or often adequate and proper. It can be concluded that adequacy and properness of the selection process do not pose an obstacle for subjects to good execution their job. Therefore, adequacy and properness of the 
Radnović B. et al.: Managerial Stress Management As An Asset In People...

selection process were identified as a source of managerial stress in the context of people management as an element of marketing strategy.

Further analysis leads to the conclusion that men have lower identification of adequacy and properness of the selection process as a source of managerial stress than women, regardless of their age, level of education, and the organization in which they work.

QUESTION NO. 7. Do you think you are appropriately paid for the work you do?

Table 11 - Earnings

\begin{tabular}{|c|c|}
\hline ANSWERS & NUMBER \\
\hline NEVER & 34 \\
\hline SOMETIMES & 41 \\
\hline OFTEN & 16 \\
\hline ALWAYS & 9 \\
\hline$\Sigma$ & 100 \\
\hline
\end{tabular}

To the seventh subject-related question, on how satisfied they are with their earnings in the process of event management, only 25 subjects, significantly less than half, answered they are always or often appropriately paid for the work they perform. Conclusion is reached that subjects' satisfaction with the earning is an obstacle to good execution of their job. Therefore, satisfaction with earnings is identified as a source of managerial stress in the context of people management as an element of marketing strategy.

Further analysis shows that women older than 40, with obtained secondary education, regardless of the organization in which they work, have higher identification of satisfaction with earnings as a source of managerial stress.

QUESTION NO. 8 - Do you feel the pressure of time and deadlines?

Table 12 - Time and deadlines pressure

\begin{tabular}{|c|c|}
\hline ANSWERS & NUMBER \\
\hline NEVER & 9 \\
\hline SOMETIMES & 32 \\
\hline OFTEN & 43 \\
\hline ALWAYS & 16 \\
\hline$\Sigma$ & 100 \\
\hline
\end{tabular}


Radnović B. et al.: Managerial Stress Management As An Asset In People...

To the posed eighth subject-related question, about time and deadlines pressure in the process of event management, 59 subjects answered they always or often feel the pressure of time and deadlines when performing their job. Conclusion reached is that the pressure of time and deadlines proves to be an obstacle for subjects to good performance of their job. Consequently, time and deadlines pressure was identified as a source of managerial stress in the context of people management, as an element of marketing strategy.

Further analysis points to conclusion that the feeling of time and deadlines pressure is stronger in employees older than 40, regardless of gender, level of education and the organization in which they work. Findings also indicate lower identification of time and deadlines pressure as a source of managerial stress in men than in women, regardless of age, level of education, and the organization where they work.

\section{Conclusions}

The aim of this paper was to demonstrate the importance of proper and timely identification of sources of managerial stress, as well as to produce recommendations for the proper management, as an asset in people management as an element of marketing strategy. A scientific-research questionnaire of universal type was defined to this effect, which can be used regardless of organization's type and activity. The research was conducted on a sample of 100 subjects in 13 different organizations in the Republic of Serbia.

Having carried out the research, the following sources of managerial stress were identified:

- participation in decision-making,

- selection process,

- earning,

- time and deadlines pressure.

The research findings indicate a high interconnection between all identified sources of managerial stress, regardless of subject's gender, age, level of education, and the organization in which subject is employed. Another important finding of this research reveals that employees are bothered by participation in decision-making, which is often present only as lip service and fails to correspond to employee's position in the organization. Furthermore, the process of selection arises as an evident source of managerial stress, including, among others, hiring, i.e. recruiting of employees, development stimulation and career prospects for staff. The reason for this certainly lies in largely present nepotism as well as in political influence during selection 
process, being the most prominent in state-owned organizations. In addition, amount of earnings proves to be an obvious source of managerial stress. Faced nowadays with global crisis, as well as crisis in Serbia lasting for several decades, employees perform regular work as they used to, but earn far less. Such a recognition and the fact the earnings in most cases rarely meet even basic needs, affect great dissatisfaction reflected in the identification of earnings as a source of managerial stress. Furthermore, an evident source of managerial stress nowadays is high time and deadlines pressure, often due to process of planning and organization of work and performance of assignments that is carried out without considering timeframe.

Given the above, and the purpose of optimal management of managerial stress in the context of people management as an element of marketing strategy, the following recommendations can be considered:

- It is necessary that each employee sufficiently participate in decisionmaking with regard to the position held in the organization. Employee's participation in decision-making should be active, encouraged, stimulated and rewarded.

- Adequacy and properness of the selection process should involve an objective external and internal recruitment and development of staff according to their competences. It is necessary to determine the methods and procedures of selection. Progress made by employee should be based solely on work performed and results achieved. Any kind of subjectivity, nepotism and political influence should be eliminated.

- There must be a clearly defined and adequate payment system, which should involve a fixed and a variable part of the salary, based solely on the results achieved at work.

- Work assignments should be given in timely manner. Contradiction between scope and complexity of work and provided timeframe for its execution, as well as capabilities of the appointed employee should be eliminated. Separate stages in work realization ought to be clearly defined. Continuous monitoring of the execution is to be conducted in order to avoid narrow timeframes. Effective time management is a must.

Combining previous theoretical achievements and practical considerations of the phenomenon of managerial stress, it can be concluded based on conducted scientific research that adequate management of managerial stress is founded on timely and accurate identification of its source. Therefore, only proper identification of the source of managerial stress evidently preconditions its appropriate management, in the context of people management as an element of marketing strategy. 
Radnović B. et al.: Managerial Stress Management As An Asset In People...

In that respect, objective of this scientific research was to provide answer to this open issue by designing a universal model, regardless of gender, age, level of education or organization's activity. A generally applicable scientificresearch questionnaire was therefore created and implemented, necessary for proper identification of managerial stress, as an asset in successful people management as an element of marketing strategy.

\section{References}

Andrejević, A. \& Radnović, V. (2010). Uticaj eksternih faktora na menadžerski stres u organizacijama. the magazine "Poslovna ekonomija" for business economics, entrepreneurship and finance, issue 1/2010, Sremska Kamenica, page 175-187.

Andrejević, A. \& Radnović, V. (2011). Uticaj internih faktora na menadžerski stres u organizacijama". the magazine "Poslovna ekonomija" for business economics, entrepreneurship and finance, issue 1/2011, Sremska Kamenica, 2011, page 375-394.

Ikač, N. (2005). Menadžment ljudskih resursa (MLJR). University of Novi Sad, Faculty of Technical Sciences, Novi Sad.

Ilić, M. \& Radnović, B. (2010). Implementacija marketing koncepta u poslovnoj praksi domaćih banaka, sa posebnim osvrtom na Vojvođansku banku ad Novi Sad. the magazine "Bankarstvo", Association of Serbian Banks, page 44-56.

Kotler, P., Wong, V., Saunders, J. \& Armstrong, G. (2007). Principles of Marketing. the fourth European edition, Mate, Zagreb

Mihailović, D. \& Borovnjak, A. (2008). Menadžerski stres. Faculty of Organizational Sciences, Belgrade

Pržulj, Ž. (2011). Menadžment ljudskih resursa. Educons University, Sremska Kamenica

Radnović, B. (2013). Marketing usluga. Faculty of Business Economics, Educons University, Novi Sad - Sremska Kamenica

Vujić, D. (2009). Menadžment ljudskih resursa i kvalitet. Prometej, Novi Sad

Veljković, S. (2009). Marketing usluga. Faculty of Economics in Belgrade, Belgrade 